\title{
Socio-Economic Realities at Work: a Study on Female Workers in the SME's Located in Malaysia
}

\author{
Nwanesi Peter Karubi, Muhammad Khalique* \\ University Malaysia Sarawak, Malaysia \\ *cks748@gmail.com
}

\begin{abstract}
This paper attempted to critically analyse the social/cultural issues faced by women in SME's located in Penang Island in the heart of Malaysia. Further, it aimed to evaluate the motives and the impact of changing jobs among the Female Factory Workers (FFW) at the SME factories located in Penang Island. SME's are mainly based on 5 to 250 employees. However, the technical definition varied from country to country in the Asia-Pacific region but was usually based on employment, assets, or a combination of the two. Some countries had different definitions for SME's in the manufacturing and services sector and may exempt firms from specialized industries or firms that had shareholdings by parent companies. The trends in many SME's' factories were to employ a large number of young girls from rural areas or other neighbouring states. The findings of the study depicted that the young women were often underpaid, housed in over-crowed hostels and some often-experienced sexual harassment and salaries withheld.
\end{abstract}

Keywords: Workforce, Female worker, Factory, Experiences, Career, Gender inequality, exploitation

\section{Introduction}

Malaysia had one of the highest employers of migrant workers from Asia was no longer a debatable issue but a fact supported by overwhelming statistics. Penang one of the ever-dynamic industrial regions of Malaysia provided work for thousands of young women from local and international countries. Most of these young women earned as little as RM450 per month for work close to 45 working hours weekly. Most of these young women were as young as 18 years, doing jobs that had no bearing to their future career development. This and other factors had continued to strengthen most female factory workers to constantly be on a look out for a new industrial unit to sell their labour. In many instances, their toil was mechanical; devoid of emotion, attachment, and sometime commitment or loyalty to their job. The hard work of these women was not compensated with the appropriate amount of wages. Thus, the principal objective of this paper was to examine the social/cultural issues faced by Female Factory Workers (FFW) at the SME ${ }^{1}$ factories located in Penang Island.

\section{Literature Review}

This research was conducted in Pinang Island, Penang state of Malaysia. The growth of this unique human settlement began with the acquisition of the Port of Penang in 1786 by the British. The extension of their rule to the Malay States in the interior laid the foundation of Penang as an urban city. This expedition (the British acquisition of Penang Port in 1786) ushered in a new era in the development of human settlement in the region (George 1972). Besides, being the centre of trade and services sector for the northern region, Penang hugely benefited from the Malaysian government programmes for industrial development, which stressed import substitution industrialization. The outcomes of this vigorous and ambitious objective of Malaysian government ushered in massive industrial establishment, growth, industrial free zone and create considerable job opportunities for many young adults especially women. In fact, most of these industrial units depended on young women to assemble products and perform other non-skilful jobs in their factories. In

\footnotetext{
${ }^{1}$ SME's are usually enterprises that employ no more than 250 employees. The technical definition varies from country to country in the Asia-Pacific region but is usually based on employment, assets, or a combination of the two. Some countries have different definitions for SME's in the manufacturing and services sector and may exempt firms from specialized industries or firms that have shareholdings by parent companies (Vadim 2007)
} 
essence, driven by the availabilities of easy-to-get jobs at Penang's sparely factories in the states' industrial free zone, many young women migrated to the Island city to join the workforce; thereby re-echoing one of the characteristics of current global industrial trend since 1930s. The increasing numbers of women in the workforce was associated with various historical factors and economical transformation. For example, in the 1930s and after the Second World War, there was an astronomically increase on the number of women entering the workforce due to a dire economic need and the shortage of men in the workforce (England and Farkas, 1986).

After the war, the number of services oriented jobs such as sales clerk, secretary, server, or nurse was rapidly taken over by women. This historical epoch recurred with the increase in demands of industrial products ushered in by the globalization process. Consequently, challenging the patriarchal undertone that men are the breadwinners of the family. Besides, women increasing numbers in the workforce was the dire need to contribute to the family's income, which enables them to, sustained the high standard of living created by socio-economic fluctuation of global economy; a phenomenon which had become a characteristic of globalization and industrial free zone. This point was strongly visible in an article by Hancock on the factors justifying the large numbers of Sudanese women on the workforce. This article noted; Twenty years ago, women, especially unmarried women, rarely left their village area and were forbidden to leave the Banjaran area alone. They were forced to leave school at 11 years of age-the age of womanhood in Sudanese culture-and were married soon after. Today, thousands of young women travelled daily to factories; some travel long distances from their homes-journeys their mothers rarely took. This change was due to economic development, but had not necessary meant the emancipation of Sudanese women (Hancock 2000). From the 1960s, the women's liberation movement was bolstered as they participated in the workforce. Thus, spreading an intriguing understanding that working outside the home was step in the right direction; because it aimed towards redressing the home-wife image to one on independence and self-reliance. What is more, the employers' and government's eagerness to increase the number of female staff at the workforce, encouraged many women to view their participation as not a mere workers riveted in provisional jobs, but as people with long term occupational or career goals. Conversely, over the years such dreams of many female factory workers had not materialized as most of them were perpetually placed in dead-end jobs and replaced or sacked at slightest industrial judder. Besides, the habitual explanation (that is, basic education is all that is needed, and no skill is required), most female workers at SME factories were employed as a 'rudimentary staff'. They were hastily trained to perform specific jobs, and they often spent their career life on the same work schedules-assembling parts or screwing details.

\section{Methodology}

This paper was the result of fieldwork carried out in Penang Industrial Free Zone in April to May 2010. As the introduction detailed, the creation of Industrial free zone and other governmental development growth policies tremendously benefited Penang and carved the state out as manufacturing heaven. As a result, it was home and workshop for thousands of young women from rural and urban areas of Malaysia and other countries in the South East Asian region. Our study collected data from 30 respondents employed by SME factories. It was a descriptive study based on observations and questionnaires distributed to employees from SME's employees in Malaysia. Simplified questions were designed keeping in mind their level of education. Five weeks of fieldwork was undertaken for a research process under which the researcher visited their place of work and observed their lifestyle both in the factory and outside their working environments. Questionnaires were distributed among seven SME industries. About 70 questionnaires were distributed, 53 questionnaires were returned, 30 were answered satisfactory and completely, eighteen questionnaires were incompletely answered, and five was returned without a comment on them. Respondents were chosen randomly based on the list provided by the various SME factories the questionnaires were distributed. The respondents had been working in these SME factories between 6 months and 4 years and above; and most of them had worked in more than one SME factories over the years. As one respondent explained in the space provided in the questionnaires: We were here to work and earn money for self, and for the people we support at home; so if the condition is not good enough there is no reason to remain in the same factory: after all, when one door closes and another opens for work. Although these women were seen as involved in a productive work, which had monetary value, including production and marketing activities however, it came at a high cost. The essence of work was to produce goods and services for one's own use or in exchange for 
pay or support. The foundation of human society had always been designed to reflect gender differences. Although the process was, gradually given way to gender equality yet there was statistics to show gender equality was a common phenomenon in every human relation especially in terms of job designation or career progression.

As Sadie and Ao (2009) argued; "New forms of gender discrimination at the workplace had emerged in more subtle ways, and usually under the disguise of protecting women, as authorities had outlawed traditional types of prejudice based on gender". Sceptics might charge that gender roles were changing at work and at home, therefore presenting the above statistic was unnecessary and does not argue well because the essence of FFWs' joining workforce was first to raise money to support their families. Such authors would not hesitate to point out that factory employment had acted as a catalyst, and most women saw the opportunity it provided them to step out of their traditional homestead. Furthermore, the essence of joining workforce was fulfilled as the women workers go home at the end of every month with enough income to solve major problems they faced prior to joining workforce. Hence, women had been provided with relatively long term and stable employment, which had affected upon their and other family members' wellbeing (see also Hancock 2000). Besides, they argued, traditionally most of these women would have been restricted by cultural guideline and norms. Anil (2003), the General Manager of South Asia Enterprise Development Facility in a paper presentation argued that; “The role of SME's in providing productive employment and earning opportunities had emerged as an important drive among policy makers, donor agencies and researchers". He mentioned that; Since the 1970s there had been growing recognition that emphasis on largescale industrialisation in developing countries had only moderate success in generating employment growth and alleviating poverty, and that enhancing the development of SME's may be crucial to fostering growth and equity... SME's enhance competition and entrepreneurship, and hence had external benefits on economywide efficiency, innovation and aggregate productivity growth. In as much as Anil (2003), understanding of the importance of SME's to economic development of a state, the presentation failed to exemplify the human cost or the underdevelopment of female factory workers that worked tirelessly to ensure goods was produced as specified. In fact, what this beautiful article failed to mentioned or acknowledge is that thousands of young women employed in these SME companies or factories had no job security, their career life was a journey in a single file; from dormitory like houses to work place and back to the dormitories.

The works they performed on daily basis in the factories had not inculcated any work experience or education that would enhance their opportunities to survive or create wealth in this modern and globalised environment. He equally failed to take into account that these young female staff were employed in precarious jobs, faced direct layoffs or easier dismissal, reduction of workdays or hours (which translated into reduction in take home income), freezes on the minimum wage. In many corporations or factories, sexism was still a common practice. It often made a great difference if you were a man or a woman. Gender roles were "socially and culturally defined prescriptions and beliefs about the behaviour and emotions of men and women (authors)". This understanding often influenced whom employers hire, the nature or type of jobs assigned, whom to promote, and set pay. In addition, the qualifications that employers required also influence whom they assign to what jobs. Some organizations require qualifications that are more common among men and unnecessary to do the job. A reflection of 1989's Mayes argument on female occupational services. According to Mayes, women comprised 40 per cent of the labour force; however, the quantitative expansion of female employment gave little cause for celebration (1989). Mayes position then was framed because "women's position in the occupational structure has not changed very much either". In essence, she argued; it had three key characteristics. First, much of women's work reflects their domestic role; the majority of cleaners, cooks, clothes makers, infant teachers, and nurses were women. Secondly, women predominate in work rules, which require deferential behaviour, such as waitressing and shop work, which require the 'female' qualities of politeness and responsiveness to the needs of others. Seeing mainly women performing these roles does little to help revaluation of those qualities or of the women themselves. Third, for many women, paid work was another job added to their domestic responsibilities. These key characteristics are propounded by most FFW prior to employment and ensured throughout the duration of their employment in these SME factories. In many ways, female factory workers replicate what Mayes (1989) tagged "Britain's hidden army". She stated this term had been coined to describe workers who perform paid work without entering the official labour force. This group she illustrated further, mainly women workers at home assembling small products such as Christmas crackers or transistor radios or sewing up clothes from pre-cut 
fabric. Perhaps the major differences was while the women Mayes tagged worked at home these young women at SME works in the factories, however, both parties assembling small products.

Briefly, most SME factories employ female workers based on the old cultural practice of gendered work. They are assigned tasks based on worker's gender. In essence, there was a higher value place on men's work than women's work. This was obvious as many of such factories employed men as supervisors, supervisors or factory manager while women were regulated to jobs that offer little or absolute skill benefit. In fact, gender roles in these factories were optimized to enrich companies while reducing female staff to mechanical tools to be used and discarded when they have exceeded their usefulness. Women are concentrated at low levels in the organizations that employ them and in lower ranks in their occupations and professions. These jobs performed by these women are dead-end jobs and were less likely to enhance their career development or salary incensement elsewhere. Overall, our date suggested that Female Factory Workers earned about 52\% of the pay rate of men. This was attributed to lack of adequate skill and most companies had no intension in providing them with such skill, hence they highly favoured their employment as 'tie and bolt' factory workers. The notion of 'adequate' as one of the manager used in his illustration was to show that the company did not set out to employ low level staff but a gesture that emphasises on fairness and equality. Furthermore, the data from the field showed gender pay discrepancy was a profound occurrence in these establishments. Moreover, for female workers that have worked longer in a particular factory, pay gap grows much wider as workers get older. In fact, while older female workers salary seemed to remain static, men's earnings in the same establishment tend to increase as they aged. Most female factory workers were between the ages of 17 and 30 years old. They were a combination of both local and migrant workers. These young women worked between 6 to 12 hours every working day at the $\mathrm{SME}^{2}$ factories. Yet they were rather used to enhance the benefits of globalization and enrich factory owners and shareholders richer. Certainly, not only their take home pay was sometimes below minimum wages, but their next step in life after they stopped working in these factories remain unknown and most cases uncertain. Supporting this uncertainty, was the fact that through our data, we could establish that about $93.5 \%$ of our respondents had no pension, retirement benefit or protected by union laws.

They are simply more or less machines used to perform specific function and discarded when their usefulness is exhausted. Their welfare and wellbeing were not fully guaranteed or even part of the companies' agenda they were constantly on the move to assure they benefited economically from many such factories. In essence, their job security was simply an illusion because they could easily be employed and the next day lay off with the infinitesimal excuses; because there were others waiting on the line to take their jobs with zero conditionality. This condition was made very easy because like most young female working in this essential industrial free zone, 97.2 per cent of our research participants were employed to perform a mono-tasking routine from the day they were employed to the day they were disengaged from such companies. Briefly, they were essentially employed to assemble machine parts. These jobs required little or no skill to perform. The little trainings they were given was the initial instructions on how to perform their duties. These instructions were passed down to new recruits within a maximum of seven days. In reality, the little skill they acquired while performing this mono-tasking schedule was often forgotten as soon as they were reassigned to a new task or resign from the said company. The above argument was further substantiated given the number of times these female workers change their companies within the shortest time of their employment. Of 30 respondents, only 26 percent had worked for the same company throughout the duration of employment in this industrial free zone; and this group belonged to those participants who had worked for less than six (6) month. As our data established, respondents that had worked in Penang SME for two years or more, are more likely to have worked for two or more different companies. Reasons given for working at various companies varies from salary withheld sexual abuse and harassment, bad working condition, lack of interest in the jobs they performed. About 49.5 per cent hinted at lack of proper training and the absence of long-term projection for staff wellbeing and job security.

\footnotetext{
${ }^{2}$ The SME factories or industries are not exception nor is Penang; they are a mere case study to represent the working condition of female factory workers in many developing countries around the world.
} 
A number of the research participants claimed to have left their first job without being paid, because they could not cope with the job demands and stress it created for them. They were at the lowest levels of casual, temporary, low paying, insecure employment with minimal or no social insurance support. Consequently, most female factory workers, supposedly believed their best chance to improve their wellbeing and earn better salary was to be constantly on the move; that was to change work place as soon as such prospect surfaces. Besides, as soon as there was a lower global demand for such export goods and services, it was no surprise that female factory staff was the first to be laid off. The low educational level coupled with lack of skill made them very vulnerable for exploitations since they lacked much needed bargaining power. Because the roles of men and women in most societies often differed, their needs vary accordingly. However, these differences were gradually becoming undefined, as many women had direct or indirectly assumed both the financial and non-financial responsibilities of their families. Yet, deficient strategies (Strategic Gender Needs and Practical Greater Needs see Caroline (1993) ${ }^{3}$ definition of these concepts) had ensured that many women faced a high degree of subordination and injustice as the data for this paper have illustrated. Besides, women's concentration in activities (especially economically) that produces low returns or locked in lowpaying jobs perpetuate stereotyped economic roles and thereby ascertain the perception that men control money and therefore control decision-making. Essence this mode of gender economic relation, sustains the age-long patriarchal tradition and a continuation of gender inequality.

\section{Conclusion}

Paid employment is important because it puts money in women's hands. There is no doubt paid job can be the path out of poverty. As the UNDP, Asia-Pacific Human Development Report 2010 (p. 57) established, this assumption has fed a heavy emphasis across the East Asia, South Asia and South East Asia and part of Asia Pacific region. The report maintained that with deregulation to boost the creation of jobs, with much less focus on social protection or even the quality of employment, it helped obscure the fact that the labour market is rife with gender inequalities. In essence this report echoing the finding of this research that many women in Asia-Pacific region consistently or often end up with some of the worst, most poorly paid jobsoften the ones that men don't want to do, or those assumed to be 'naturally' suited to women. As the gender gap in earnings has persisted, and biases go unchecked, policymaking remains partially blind to the potential of women in paid job workforce as well as to the principles of fairness and equal opportunity (see the UNDP, Asia-Pacific Human Development Report 2010). Although there has been progress in reducing it in some countries yet, the reduction in the gap reflects mainly the experience of women in full-time "formal" employment in larger places of work and does not necessarily imply that gap has narrowed for the majority of women who work in part-time or "informal" employment in small-scale place of work or at home. Besides, the quality of employment has not increased in the same way, and may even have deteriorated. Women's jobs tend to enjoy less social protection and employment rights than do men's jobs. As established in this article, most female factory workers in export-oriented manufacturing are constantly affected with the fluctuation of global economy. Hence, they are employed in precarious jobs, face direct layoffs or easier to dismissal, reduction of workdays or hours (which translated into reduction in take home income), freezes on the minimum wage.

\footnotetext{
${ }^{3}$ Strategic Gender Needs are the needs women identify because of their subordinate position in society. They vary according to particular contexts, related to gender divisions of labour, power and control, and may include such issues as legal rights, domestic violence, equal wages, and women's control over their bodies. Meeting SGNs assists women to achieve greater equality and change existing roles, thereby challenging women's subordinate position. Practical Greater Needs (PGNs) are the needs women identify in their socially accepted roles in society. PGNs do not challenge, although they arise out of, gender divisions of labour and women's subordinate position in society. PGNs are a response to immediate perceived necessity, identified within a specific context. They are practical in nature and often inadequacies in living conditions such as water provision, health care and employment.
} 


\section{Reference}

Anil, S. (2003). Experience of SME's in South and South-east Asia, Dhaka

Caroline, O. N. M. (1993). Gender Planning and Development: Theory, Practice and Training, Routledg, London

England, P. \& Farkas, G. (1986). Integrating the Sociology and Economics of Employment, Compensation, and Unemployment. Research in the Sociology of Work, 3, 119-146.

George, W. P. (1972). Penang. Singapore, Asia Pacific Press.

Hancock, P. (2000). The Lived experience of female factory workers in rural West Java. Labour and Management in Development Journal, 1(1).

Mayes, P. (1989). Gender. New York: Longman Group UK Ltd.

Sadie, Y. \& Ao, L. (2009). Legal protection against gender discrimination in the workplace in China. Gender \& Development, 17(2).

UNDP (2010). Asia-Pacific Human Development Report: Power, Voice, and Rights- A Turning Point for Gender Equality in Asia and the Pacific, India Macmillan, Publishers

Vadim, K. (2007). Small and Medium Enterprises and ICT. Bangko: UNDP Regional Centre. 